\title{
System Dynamics Development Model for Operations Strategy in Power Generation System through Integrated Transmission and Distribution System
}

\author{
Lilia Trisyathia Quentara ${ }^{1}$, Erma Suryani ${ }^{1}$
}

\begin{abstract}
Electrification Ratio in East Java (Indonesia) has reached $86.67 \%$ at the end of 2015 due to in Madura island only 60.55\% who have received electricity supply from PLN. The topography of Madura which far-flung distances per village, as well as the small number of households in the village are being constraint in build up the electricity infrastructure investment. The main problem in electrical operating system is how to meet the demand and supply of electric power by maintaining the continuity of effective and efficient services to PLN customers. These problems would take a long-term solution in electrical system which is able to increase the role of renewable energy, improve the reliability, safety and efficiency, reduce energy costs, and can recover quickly from interruptions. Effective and efficient electrical operational systems in real time is expected to improve the sustainability of supply electric power. The Dynamic System method is used to analyze the electrical operating system by developing a scenario model to identify the factors and variables that affect the system, to be use-full as consideration in taking strategic policy in operational PLN.
\end{abstract}

Keywords - Dynamic System, Model Scenario, Power Generation System, Transmission System, Distribution System, Causal Loop Diagram, Electrification Ratio.

\section{INTRODUCTION}

$\mathrm{E}$ lectricity has become an essential need in everyday life for the people so that the demand for electric power will continue to increase every year. The increasing in electricity consumption has caused the energy consumption also as the main resources for power generation. In last ten years (2003 - 2013) energy consumption in Indonesia increased by $5.5 \%$ per year. The energy reserves of crude oil, gas and coal will run out in 22.99 years, 58.95 years and 82.01 years[1]. These numbers declined continuously in line with the increasing of electricity demand, which average growth $8.7 \%$ per year in the period 2015-2024 as seen in Table 1.

The current main energy resources that used in electricity generation system still relies heavily on natural oil and coal. Although there are a lot of potential for new renewable resources in Indonesia, but its utilization is still not explored optimally by the government. Therefore, some research on renewable energy in power generation becomes an important thing that should be implemented immediately in order to minimize the use of unrenewable energy resources.

\footnotetext{
${ }^{1}$ Lilia Trisyathia Quentara and Erma Suryani are with Department of Information System, Institut Teknologi Sepuluh Nopember, Surabaya, 60111, Indonesia. E-mail: lilia.quentara@gmail.com; erma.suryani@gmail.com.
}

TABLE 1. ENERGY DEMAND ESTIMATION

\begin{tabular}{|c|c|c|c|c|c|c|c|c|}
\hline Uraian & Sat & $2041 *$ & 2015 & 2016 & 2018 & 2020 & 2022 & 2024 \\
\hline $\begin{array}{l}\text { 1. Energi } \\
\text { Demand }\end{array}$ & Twh & & & & & & & \\
\hline - Indonesia & & 201,5 & 219,1 & 238,8 & 282,9 & 332,3 & 392,3 & 464,2 \\
\hline - Jawa Bali & & 153,6 & 166,4 & 178,3 & 207,1 & 239,5 & 278,6 & 324,4 \\
\hline $\begin{array}{l}\text { - Indonesia } \\
\text { Timur }\end{array}$ & & 20,0 & 22,6 & 25,8 & 33,1 & 40,0 & 47,8 & 57,1 \\
\hline - Sumatra & & 27,9 & 31,2 & 34,7 & 42,7 & 52,8 & 65,9 & 82,8 \\
\hline 2. Pertumbuhan & $\%$ & & & & & & & \\
\hline - Indonesia & & 8,6 & 8,7 & 9,0 & 8,9 & 8,4 & 8,7 & 8,8 \\
\hline - Jawa Bali & & 8,2 & 7,6 & 7,8 & 7,6 & 7,5 & 7,9 & 7,8 \\
\hline $\begin{array}{l}\text { - Indonesia } \\
\text { Timur }\end{array}$ & & 12,2 & 12,9 & 14,5 & 14,2 & 9,9 & 9,2 & 9,2 \\
\hline - Sumatera & & 11,7 & 11,7 & 11,1 & 11,1 & 11,2 & 11,8 & 12,2 \\
\hline $\begin{array}{l}\text { 3. Rasio } \\
\text { Elektrifikasi }\end{array}$ & $\%$ & & & & & & & \\
\hline - Indonesia & & 84,4 & 87,7 & 91,3 & 95,7 & 98,4 & 99,1 & 99,4 \\
\hline - Jawa Bali & & 86,8 & 90,5 & 94,6 & 98,4 & 99,8 & 99,9 & 99,9 \\
\hline $\begin{array}{l}\text { - Indonesia } \\
\text { Timur }\end{array}$ & & 76,1 & 79,2 & 82,1 & 87,9 & 92,9 & 95,8 & 97,5 \\
\hline - Sumatera & & 84,8 & 87,2 & 89,8 & 95,0 & 99,2 & 99,9 & 99,9 \\
\hline
\end{tabular}

Indonesia's electrification ratio has reached $81.70 \%$ at the end of 2014. In beginning 2015, BPS said there were still $15.40 \%$ of the villages that not electrified yet, spread in 511 districts / cities in 33 provinces. Indonesia's ratio electrification gaps and supply electricity for urban areas reached $94 \%$, while in rural areas only $32 \%$, the bottom among other ASEAN countries. Otherwise Thailand has balanced the electrification ratio of $99 \%$, Malaysia only differs $1.4 \%$ (99.4\% cities and villages $98 \%$ ), and Vietnam only $13 \%$ where $98 \%$ in cities and the villages $85 \%$. 
In East Java Province, not all the districts have been able to get the electricity facilities, as in 2014 the electrification ratio has reached $83.14 \%$ and by the end of 2015 has increased to $86.67 \%$. Madura Island is part of East Java Province, which is from a total of 1,005,386 heads of families (KK), only around 608,798 households have been electrified now. These, caused the range of electrification ration only has reached $60.55 \%$, but in the small islands around Madura was still have not touch $40 \%$.

Based on the official data from PLN Pamekasan Area which responsible for electricity in Madura, the uneven flow of electricity in the southern and northern regions due to inadequate road infrastructure. Electricity infrastructure is strongest in the southern region of mainland Madura because the transmission lines built in the southern region, ranging from the longest, Bangkalan, Blega, Sampang, Pamekasan and Sumenep. To facilitate electrical service to the northern region of Madura, namely Ambunten, Waru, Ketapang and Tanjung Baru, PLN needs to provide a long cable electricity power in middle level voltage and this temporary solution caused higher energy losses in distribution system.

PT. PLN (Persero) as a monopoly company that manage electricity in Indonesia continue to boost the increasing of electrification ratio be $100 \%$ by launching a $75-100$ vision, which is the achievement the value $100 \%$ electrification ratio in Indonesia before the $75^{\text {th }}$ celebration of the Independence of the Republic of Indonesia in 2020. This target is a big agenda that require collaboration between PLN and local government and also Independent Power Producer (IPP) to succeed the rural electrification program which has been launched by the government.

There were 4 districts wide area in Madura Island, Bangkalan, Sampang, Pamekasan and Sumenep, which consist of some villages and small islands. Many villages in the fourth district have not electrified yet, as example in Bangkalan 50 villages, 78 villages in Sampang, 50 villages in Pamekasan and 32 villages in Sumenep[2]. Topography in Madura which the distance between villages is far away and also the geography factor like the hill-ground and some small islands separate by the ocean, become main problems for PLN to prepare electricity infrastructure.

The first purpose of this research is to identify the factors which is caused the constraints and barriers in electrical supply system for Madura. After define them, the next purpose is make formulation and list in any variable in each factor to develop a simulation model in order to analyze the effective and efficient electrical operational system. System dynamics development model, which is the final purpose in this research was used to predict the future condition by considering the dominant factors in causality diagram for a decision process.

In transmission system, the parameter reliability measurement is used System Outage Frequency (SOF) and System Outage Duration (SOD)[3]. The value of SOF and SOD means for how long and how many times the outage happened in system and how fast the system will recovery after interruption. The main caused of outage system might be happened by the environment, human error, and the quality of tools and material machine [4]. Distribution system also has its own parameter to measure the reliability, like System Average Interruption Frequency Index (SAIFI), System Average Interruption Duration Index (SAIDI), and Customer Average Interruption Duration Index (CAIDI)[5][6].

Electrical operational system consists of power generation system, transmission system and distribution system. Effective and efficiency in electrical operational system is improvement process for power generation, transmission and distribution system by decreasing the workload operation and maintenance and energy consumption. These, inline with three main keys in Smart Grid concept, e.g: increase the energy efficiency, increased reliability and stability of electricity supply and reducing emissions of carbon dioxide $\left(\mathrm{CO}_{2}\right)$. Therefor in this research, we address the causality relationship in integrated electrical operational system.

The research questions for this study are:

1. How is the reliability of electrical supply in Madura, what are the constraints and barriers that inference the electrical operational system.

2. What factors are important to determine the priority variables to analyzed an operational system being effectively and efficiently.

How to integrate the power generation, transmission and distribution system to create a balance supply and demand of electricity for customers in Madura Island.

\section{METHOD}

This research used quantitative approach and take place in Madura (East Java, Indonesia). Historical data in simulation are collected from the monthly and yearly reports from PLN East Java Distribution, PLN Pamekasan and global issue in Indonesia government news and policy.

System dynamics method was used in this research to analyze the system for giving more alternative in simulation process. First step of all was defined and identified the currently problems in electrical operational system to understanding the whole system before make a new concept for modelling which represented the real system. Simulation with Ventana Simulation tools figured out the predominant factors and variables in system.

Otherwise, the development model should pass two step of validation process to determine whether it is an acceptable to represent the real system or not. The first validation test is a statistical comparison of the average (mean comparison), and the second test is amplitude variation ratio (percentage of error variance). Mean Comparison $\left(E_{1}\right)=$

$\underline{\mid \text { Simulation Average Value }(\bar{S}) \mid- \text { Data Average Value }(\bar{A})}$ Data Average Value $(\bar{A})$

Error Variance $\left(E_{2}\right)=$ $\mid$ Simulation Stdev Average $\left(\overline{S_{S}}\right)-$ Data Stdev Average $\left(\overline{S_{a}}\right) \mid$

Average Value of Data Standart Deviation $\left(\overline{S_{a}}\right)$

The following flow diagram in Figure 1 shows the detail step in this research which done from the beginning to the Causal Loop Diagram (CLD) as the result. 


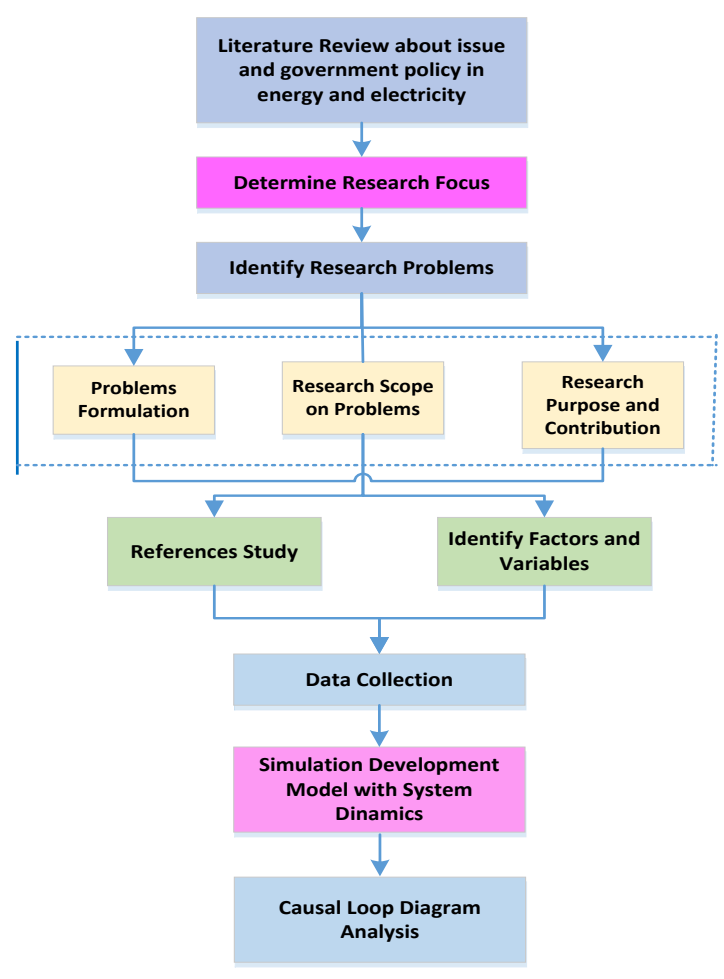

Figure 1. Flow diagram research methodology

As the final step for the research is develop a Scenario Model by considering its structure or parameters to be recommended in new electrical operation system for create a better electrical operation system than before.

\section{RESULT AND ANALYSIS}

The integrated electrical operational system in this research was divided into 5 sub system, e.g.: (1) Energy Balance, (2) Electricity Demand, (3) Electrification Ratio, (4) Reliability System Transmission, and (5) Reliability System Distribution. Each sub system has its own development model configuration, which is describing in detail the causality relationship between variables. Some factors and variables that affect the system currently were listed in Table 2.

TABLE 2. VARIABLES IN OPERATIONAL SYSTEM

\begin{tabular}{|c|c|c|}
\hline No. & Sub Model & Variables \\
\hline 1 & Energy Balance & $\begin{array}{l}\text { Energy Transmitted, Energy Received, Energy } \\
\text { Louses, Efficiency Energy }\end{array}$ \\
\hline 2 & $\begin{array}{l}\text { Electricity } \\
\text { Demand }\end{array}$ & $\begin{array}{l}\text { Connected Capacity Supply for Customers } \\
\text { (household, business, industry, public, and } \\
\text { social), Estimated demand capacity for } \\
\text { electricity }\end{array}$ \\
\hline 3 & $\begin{array}{l}\text { Electrification } \\
\text { Ratio }\end{array}$ & $\begin{array}{l}\text { Number of Customer (household, business, } \\
\text { industry, public and social), growth ratio, } \\
\text { Total Madura's household }\end{array}$ \\
\hline 4 & $\begin{array}{l}\text { Reliability } \\
\text { Transmission }\end{array}$ & $\begin{array}{l}\text { SAIDI, SAIFI, CAIDI, Blackout Duration, } \\
\text { Blackout Frequency, Number of Blackout } \\
\text { Customer }\end{array}$ \\
\hline 5 & $\begin{array}{l}\text { Reliability } \\
\text { Distribution }\end{array}$ & $\begin{array}{l}\text { SOD, SOF, Interruption Duration, Interruption } \\
\text { Frequency }\end{array}$ \\
\hline
\end{tabular}

These variables were determined by updating the global issue about electricity in Indonesia, the government and the prime minister policy about energy, electricity and cooperation between department and others, and some electricity formulations in calculating the historical data in sub system.

Some formulations in sub model also created a causality relationship among variables. Any variables with its own value is used to calculate for simulation process later, and its result was similar to empirical data. The formulations are shown in Table 3.

TABLE 3.

FORMULA IN SUB SYSTEM

\begin{tabular}{|c|c|}
\hline $\begin{array}{l}\text { Energy } \\
\text { Transmitted }\end{array}$ & $\begin{array}{c}\text { Energy Transmitted }=\text { Production Supply }+ \text { Other Supply } \\
+P 3 B \text { Supply }\end{array}$ \\
\hline Energy Looses & Energy Looses $=$ Energy Transmitted - Energy Received \\
\hline $\begin{array}{l}\text { Energy } \\
\text { Efficiency }\end{array}$ & Energy Efficiency $=\frac{\text { Energy Transmitted }}{\text { Energy Received }} \times 100 \%$ \\
\hline $\begin{array}{l}\text { System Average } \\
\text { Interruption } \\
\text { Frequency Index }\end{array}$ & SAIFI $($ minutes $/$ cust $)=\frac{\sum(\text { Number of Blackout Customers })}{\text { Total Customers }}$ \\
\hline $\begin{array}{l}\text { System Average } \\
\text { Interruption } \\
\text { Duration Index }\end{array}$ & $\begin{array}{l}\text { SAIDI(minutes } / \text { cust }) \\
=\frac{\sum(\text { Blackout Duration } \times \text { Number of Blackout Customers })}{\text { Total Customers }}\end{array}$ \\
\hline $\begin{array}{l}\text { Customer } \\
\text { Average } \\
\text { Interruption } \\
\text { Duration Index } \\
\end{array}$ & CAIDI $($ minutes $/$ blackout $)=\frac{S A I D I}{S A I F I}$ \\
\hline $\begin{array}{l}\text { System Outage } \\
\text { Duration }\end{array}$ & $\operatorname{SOD}($ minutes $/ \mathbf{1 0 0} \mathbf{k m s})=\frac{\text { Duration of Interruption }}{\text { Transmission Line Leght }}$ \\
\hline $\begin{array}{l}\text { System Outage } \\
\text { Frequency } \\
\text { (kali/100kms) }\end{array}$ & SOF $($ minutes $/ \mathbf{1 0 0 k m s})=\frac{\text { Number of Interruption }}{\text { Transmission Line Leght }}$ \\
\hline $\begin{array}{l}\text { Electrification } \\
\text { Ratio (ER) }\end{array}$ & $\boldsymbol{E} \boldsymbol{R}=\frac{\text { Number of Household Customers }}{\text { Total of Household in Madura }} \times 100 \%$ \\
\hline
\end{tabular}

Causal Loop Diagram (CLD), which is the integrated variables and formulation from Table 2 and Table 3 , is a model development in representation of the real system. It was used to analyze the electrical operation systems by determined all variables that interacts each other in system and also have impact to the system. All sub system in electrical operational system, was represented the power generation system (energy balance), transmission system (reliability transmission), distribution system (reliability distribution), customer needs (electricity demand and electrification ratio).

\section{A. Energy Balance Sub System}

Electrical Energy Balance is the balancing condition between quantity electricity energy which ready for transmission (energy transmitted) and the electrical energy sold (energy received) to customer. Based on historical data from 2000 to 2015 , electricity energy transmitted to the East Java province has rose by an average $5.4 \%$ annually, while Madura itself has increased an average of $6.5 \%$ per year.

In this condition, it will be found energy losses, which is the different amount of electrical energy received that is less $20-25 \%$ than the energy transmitted. Energy losses usually happen in infrastructure transmission system and distribution system. The energy losses have led to continuous financial loss for PLN and also the deficit of power supply to customers, if not immediately solve the main problem in system. Energy efficiency (energy efficiency) can be determined by comparing the data of electrical energy transmitted to the electrical energy received.

The model development for energy balance sub system can be seen in Figure 2. 


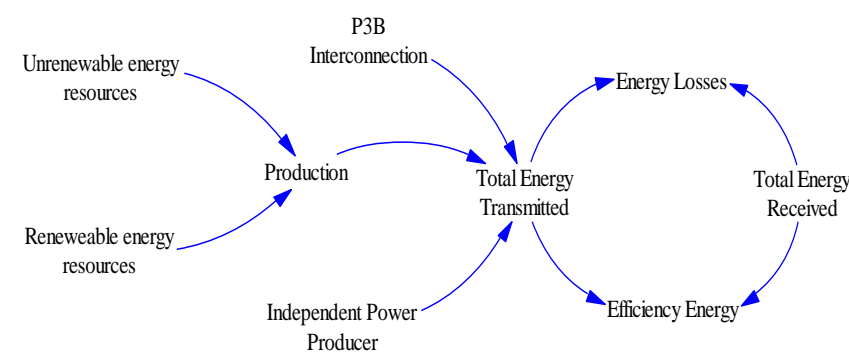

Figure 2. Causal Loop Diagram Energy Balance Sub System

One cause of the electrical energy losses that occur in Madura is due to structural problems which substations (Gardu Induk/GI) was built in southern coast region and then distributed to the northern coastal areas. The weak electrical structure in Madura is also because it was dominated by household customers, and should be improved in the event of changes in the composition of the customer for such high voltage industrial plant.

\section{B. Electricity Demand Sub System}

According to group rates, PLN split the customer group into four parts, namely the household (R), a business group (B), industry groups (I) and the Group of Public and Social (PS). Electricity consumption per customer is approached by an increasing trend of consumption, where the growth in electricity demand for labor force growth reflect the occurrence of Industry, Business, Public and Social and the population growth and household influence the increase in household customers' needs[7]. Developing countries affect the economic growth of electric energy consumption[8].

The model development for electricity demand sub system can be seen in Figure 3.

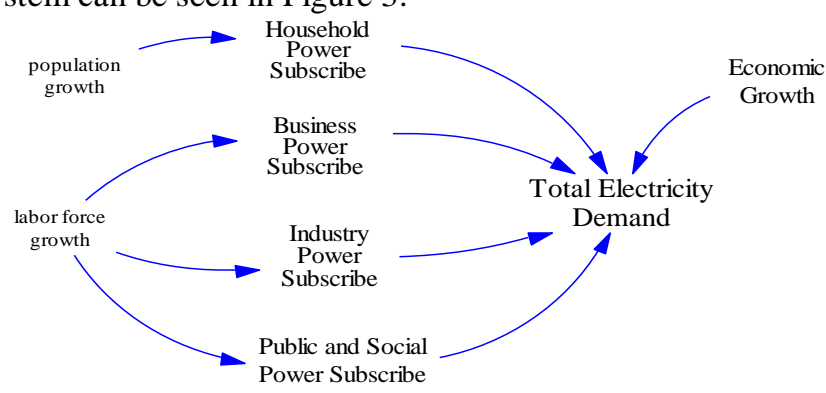

Figure 3. Causal Loop Diagram Electricity Demand Sub System

Household customers remains a top priority that must be first serve by PLN because of considering the electric power used in this group absorb an average of $81.34 \%$ of the total power supply. Power consumption for business groups, industry, public and social only ranges respectively $7.44 \%, 2.78 \%$ and $8.44 \%$ of all.

\section{Electrification Ratio Sub System}

PLN is obliged to provide electricity in sufficient quantities to people throughout Indonesia continuously, both in the short term and the long term through the planning system of the generation, transmission and substation and distribution network. For East Java, to achieve the electrification ratio $100 \%$, the target was set in Rencana Umum Kelistrikan Nasional (RUKN) for the years 2015-2034 that can be seen in Table 4.
TABLE 4.

ELECTRIFICATION RATIO TARGET

\begin{tabular}{lcccccccc}
\hline \hline \multicolumn{1}{c}{ TAHUN } & $\mathbf{2 0 1 5}$ & $\mathbf{2 0 1 6}$ & $\mathbf{2 0 1 7}$ & $\mathbf{2 0 1 8}$ & $\mathbf{2 0 1 9}$ & $\mathbf{2 0 2 0}$ & $\mathbf{2 0 2 1}$ & $\mathbf{2 0 2 2}$ \\
\hline Rasio & 86.74 & 89.67 & 92.4 & 94.92 & 97.23 & 99.61 & 100 & 100 \\
Elektrifikasi & & & & 2.7273 & 2.4336 & 2.4478 & 0.3915 & - \\
Pertumbuhan & & 3.3779 & 3.0445 & 2.72 & \\
\hline \hline
\end{tabular}

The model development for electrification ratio sub system can be seen in Figure 4.

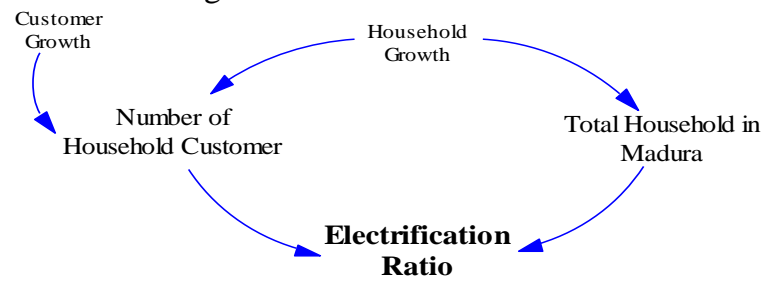

Figure 4. Causal Loop Diagram Electrification Ratio Sub System

The value of electrification ratio shows there are still villages in that area that have not been electrified yet. In Madura the village distance with its neighborhood is far and tend to isolated like hill-ground area. Deficit electricity power supply for un-electrified villages also because of infrastructure not feasible for electricity facilities. However, the government must run a program of rural electricity which is the Government's policy in the electricity sector for the expansion of access to electricity in areas not reached by the distribution network in rural areas, hoping to boost the electrification ratio.

\section{Reliability Transmission Sub System}

Because of the development in information and technology, data communication is needed to process the information and technology to monitor and control the progress of an electrical operation system remotely in realtime in order to improve the quality service to customers, including the interruption in transmission network and distribution network.

The model development for reliability transmission sub system can be seen in Figure 5.

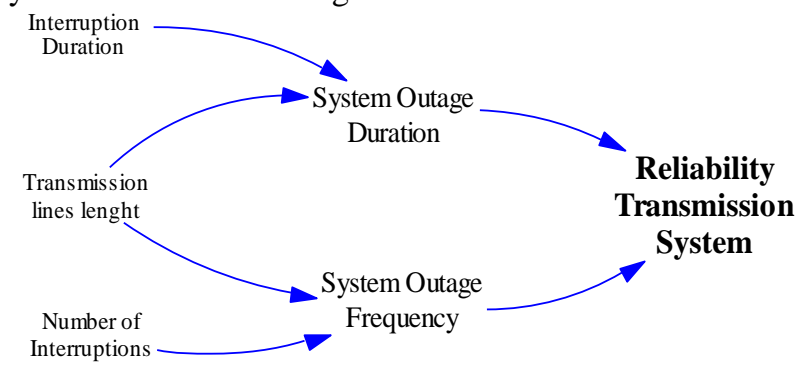

Figure 5. CLD Reliability Transmission Sub System

The SOF value and SOD value for Madura was represented from East Java interruption. Due to 2010 to 2015 year, there was no interruption occurs in transmission network, it means the reliability transmission system is $100 \%$ perfect and goes well.

\section{E. Reliability Distribution Sub System}

The distribution network is performed to be reliable if the network is a low reactor shutdown frequency and voltage quality according to the standard, so that the quality of service depends on the duration and frequency of outages that occurred. Mostly the interruption in 
distribution system caused by external problem because of human error, the weather, and environment.

The model development for reliability distribution sub system can be seen in Figure 6.



Figure 6. CLD Reliability Distribution Sub System

The minimum SAIDI was 99.25 minutes and maximum level in 394.98 minutes. The range value for SAIFI for Madura was occurred 2.35 to 7.07 times. The variance value showed there were technical and non-technical interruption happened during the system in one year. SOF, SOD, SAIDI, SAIFI, and CAIDI value was classified into 3 level performance appraisal, good - average - poor, in order to calculate the persentage of reliability system in year.

\section{F. Integrated Electrical Operational System}

PLN is trying to meet the power requirements that increase by also improving the quality of services, so that the reliability of the power supply and its continuity is maintained. Reliability of supply of electrical power is being target to achieve customer satisfaction. In line with the vision of PT. PLN (Persero) as the only BUMN which is engaged in supplying to the distribution of electricity it must provide the best service to its customers by improving the quality and quantity of electricity supply.

The joined model as the integrated relationship among sub system before is presented in Figure 7.

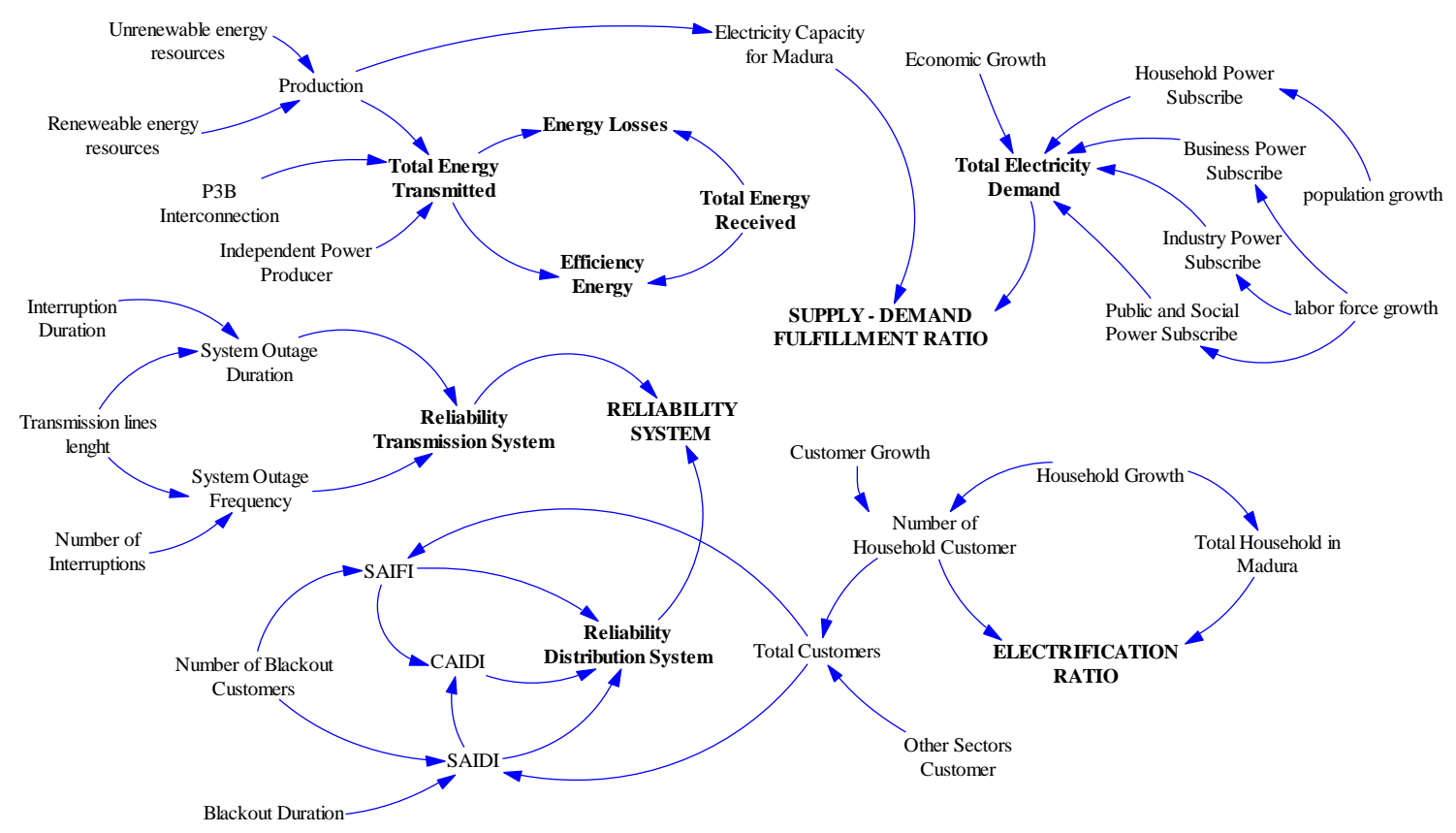

Figure 7. CLD Integrated Relationship Sub System

After 2010, as the Suramadu Bridge is fully functionally, the supply for electricity power has increased from 80 Megawatt (MW) to 200 Megawatt. PLN has utilized it to connect the power cable to distribute the electricity to Madura, which a positive impact on the development the long bridge.

Since 2014 the government has committed to realize the supply of electricity of 35,000 MW within a period of five years, until 2019 later. With a projected economic growth of 6-7\% a year, accounted for the domestic power capacity addition at least 7.000MW per year. Because the limitation of unrenewable energy has been important issue lately, PLN east java distribution should cooperate with UPJ Pamekasan and Local government to explore potency resources in Madura. Even though the reliability system was in good performance, but the amount of un-electrified area still need to be count in to make PLN performance appraisal.

\section{CONCLUSION}

A proper planning is required for operations strategy in Power Generation System, so that it will support the investment decision. Madura Island is special case for electricity project because of some non-technical factors should be considered in order to implement the new power plant development. The isolated villages and island in Madura made the feasibility study is not economics in calculation, but despite all the value, people in those areas have right to get electricity facilities.

Research results show that it is necessary to increase the number of power supplies in Madura to meet future electricity demand. Additional supply of electricity can be generated by reducing the energy losses that occur, increasing the production of electricity independently of the natural resources (renewable energy and un-renewable 
energy) that exist in Madura or by requesting additional supply of P3B.

\section{REFERENCES}

[1] Ministry of Energy \& Mineral Resources Indonesia, Permen 2015$24 \mathrm{ttg}$ Pedoman Penyusunan RUK.pdf. Jakarta: Ministry of Energy \& Mineral Resources.

[2] Ministry of Energy \& Mineral Resources Indonesia, RUPTL PLN 2016-2025.pdf. Jakarta: Ministry of Energy \& Mineral Resources Indonesia, 2016.

[3] P. F. Adipraja, "Manajemen Aset Jaringan Distribusi Energi Listrik untuk Meningkatkan Keandalan Jaringan (Studi Kasus PLN Pamekasan)," Institut Teknologi Sepuluh Nopember, 2015.

[4] N. Widyastuti, "Analisis Gangguan Sistem Transmisi Listrik
Menggunakan Metode Root Cause Analysis," Ind. Eng. Online J., vol. 3, no. 3, pp. 1-8, 2014.

[5] M. Soleh, "Desain Sistem SCADA Untuk Peningkatan Pelayanan Pelanggan Dan Efisiensi Operasional Sistem Tenaga Listrik di APJ Cirebon," IncomTech, J. Telekomun. dan Komput., vol. 5, no. 1, pp. 25-44, 2014.

[6] S. Saodah, "Evaluasi keandalan sistem distribusi tenaga listrik berdasarkan saidi dan saifi," in Seminar Nasional Aplikasi Sains dan Teknologi 2008 - IST AKPRIND Yogyakarta, 2008, pp. 45-51.

[7] S. Sudirham, "Prakiraan Kebutuhan Tenaga Listrik Berbasis Pertumbuhan Jumlah Pelanggan." pp. 1-8, 2012.

[8] J. Chontanawat, L. C. Hunt, and R. Pierse, "Does energy consumption cause economic growth?: Evidence from a systematic study of over 100 countries," J. Policy Model., vol. 30, no. 2, pp. 209-220, 2008. 